\title{
Modelling of biomass fractions and radial increment of the selected Norway spruce forest stands in the region of the Moravian-Silesian Beskids
}

\section{Milan Palát}

Faculty of regional development and international studies, Mendel University in Brno, Zemédèlská 1, 61300 Brno, Czech Republic, ${ }^{*}$--mail:palat@mendelu.cz

\begin{abstract}
Palát Milan, 2015: Modelling of biomass fractions and radial increment of the selected Norway spruce forest stands in the region of the Moravian-Silesian Beskids.- Beskydy, 8 (1): 9-25

Norway spruce (Picea abies /L./ Karst.) appears to be the most important conifer species in our mountain regions. Statistically significant differences were determined in the diameter and height increments for particular types of branching. There were verified regression functions for estimation biomass fractions. Using model calculations, fractions of above-ground and underground biomass were determined for selected permanent sample plots of the Moravian-Silesian Beskids from lower altitudes. Statistically significant differences were determined in the diameter and height increments for particular types of branching. From the branching type 1.5 (fascicle/ comb-shaped) across type 2 (fascicle-shaped) and type 2.5 (fascicle/plate-shaped to type 3 (plate-shaped) both d.b.h., total tree height and radial increment decrease. For a man-made Norway spruce ecosystem regression functions determined by fitting the data from 45 sample spruce trees were derived (at Drahanská Upland) and used also for sample plots in Beskids.
\end{abstract}

Keywords: Norway spruce, biomass fractions, modelling of biomass flow, type of branching, radial increment

\section{Introduction}

Norway spruce (Picea abies /L./ Karst.) appears to be the most important conifer species in our mountain regions. As a Eurasian tree species it occupies an extensive natural range. It is due to its considerable morphological variability which is a precondition for adaptability. In autochthonous stands, spruce forms various ecotypes (upland, mountain, high-elevation) which consist of various phenotypes differing in many qualitative as well as quantitative features. The paper deals particularly with various types of branching (position of branches of the 2nd and higher orders) because branching primarily affects predispositions to increment and stress caused by climatic factors - namely wind. Each of the types of branching shows different tolerance to harsh climatic factors, particularly wind, snow, hard rime and glazed frost. Based on literature data, it is possible to suppose that foresters already at the beginning of their purposeful Norway spruce growing were aware of a certain dependence between spruce increment and its type of branching. We decided, therefore, to study in detail the relationship between the type of branching and increment in the region of the Moravian-Silesian Beskids in trees situated in permanent sample plots (PSP) of Lesprojekt (Institute for Forest Management, Brandýs nad Labem) and sample plots (SP) at the Bílý Kř́ž locality selected in such a way to cover the 5th-7th forest vegetation zones. After detailed phenotypical classification of the trees we examine also relationships between mechanical 
damage to trees caused by climatic factors and type of branching. In addition to this, we try to study possibilities of early classification of particular types of branching using annual ring analyses. The paper is a follow-up of previous papers (Palát 1985; Hauck, Palát 2000).

\section{Material and methods}

To evaluate spruce phenotypes, the relevant part of Samek methodology was applied (Samek 1964). Type of branching are depicted in Fig. 1. For statistical processing the qualitative features on the basis of their field records temporary characters $1 / 2$ and $2 / 3$ we replaced by numbers 1.5 and 2.5.

\section{Type of branching}

(1) comb-shaped

(1/2) fascicle/comb-shaped, comb-shaped/ fascicle

(2) fascicle

(2/3) plate-shaped/fascicle, fascicle/ plate-shaped

(3) plate-shaped

For 4 types of branching confidence intervals were determined for $\mathrm{P}_{0.05}$ of d.b.h. and total length of spruce in 1981, 1986 and 1991 in PSP and in 1987 and 1991 in SP of the Bílý Kř́ž locality. Confidence intervals were also determined of the annual radial and height increments in 1981-1991 in PSP and in 1987-1991 in SP of the
Bílý Kříž locality. The PSP have been already evaluated (Palát 1980, 1985; Hauck, Palát 2000) from the viewpoint of soil characteristics and air pollution, snow and wind damage as well as deer barking, insect pests, fungi and other agents.

In order to assess growth dynamics in young trees by means of annual ring analyses, Norway spruce trees in young stands in the Bílý Kříž locality were selected. Increment cores were taken by the Pressler borer from sample plot trees at b.h. $(1.3 \mathrm{~m})$ both from the eastern and western directions from 11 trees of each of the branching types (comb-shaped type was absent), i.e. 44 trees in total. Means from both increment bores were taken for the evaluation. Annual rings were measured by the Zeiss stereo-magnifying glass with the object-lens magnification $0.63 \mathrm{x}$ and turning orthoocular magnification $15 \mathrm{x}$.

Some 15 spruce sample trees were taken in each of three localities (Mrákotín 711, Rájec 13 $\mathrm{b}_{2}$, and Rájec $10 \mathrm{~d}_{1}$ ), i.e. 45 sample trees in total (Vyskot 1981). The Rájec-Jestřebí experimental station is situated in a geographical complex of Drahanská Upland. The present Norway spruce monoculture was established at the turn of the century; consequently it means that the artificial spruce pure stand is in its first generation and is about 90 years old. It is located on the eastern slope of the watershed ridge oriented in the $\mathrm{N}$-S direction at an altitude of $625 \mathrm{~m}$. The slope in a length of about $600 \mathrm{~m}$ sinks from the watershed ridge $(640 \mathrm{~m})$ eastward of the experimental plot to the valley plain of the Němčice creek being at altitudes of 590-570 m.

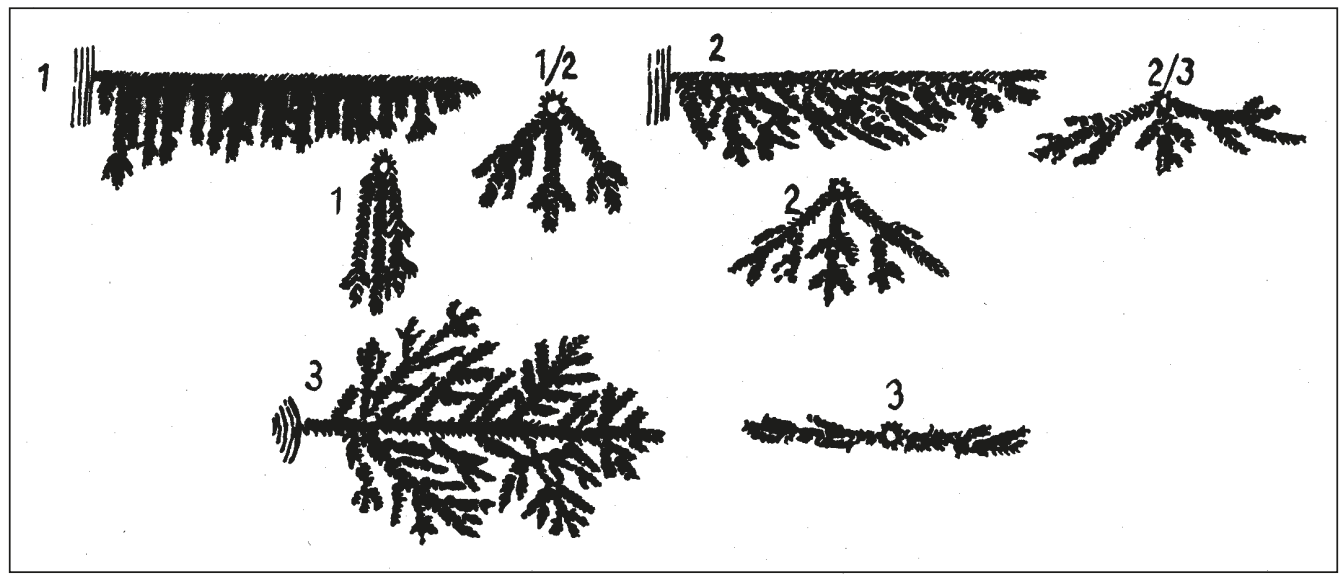

Fig. 1: Types of branching. Legend: 1- comb-shaped, 1/2 - fascicle/comb-shaped, comb-shaped/fascicle, 2 -fascicle, 2/3-plate-shaped/fascicle, fascicle/plate-shaped, 3 - plate-shaped. 


\section{Results and discussion}

Examples the type of branching are presented in Figs. 2-6. On the basis of studies carried out on 1336 trees in the Beskids, in old stands (PSP) the fascicle type predominates (51\%) whereas in younger stands (SP) it is the plate-shaped/ fascicle type (36\%). Older stands are more balanced as for the distribution of phenotypes because from six stands under study the fascicle type predominates in four of them, in remaining two stands the plate-shaped/fascicle type prevails. In younger stands (SP) in the Bílý Křriž locality, only one of five SP exhibits the fascicle type, three stands fascicle/plate-shaped branching and one plate-shaped type of branching. In general, it is possible to say that the fascicle type predominates in all plots (45\%) followed by the fascicle/plate-shaped type (31\%), comb-shaped/ fascicle type (12\%) and plate-shaped (11\%); comb-shaped type of branching appears to be nearly negligible (0.7-1.0\%).

With respect to the fact that plate-shaped and fascicle/plate-shaped types exhibit lower increment being at the same time mostly subject to windbreak and snow break it is possible to remove them in the course of thinning operations unless it is the case of summit mountain locations where just these types are advantageous being more resistant to winds.

Fitted curves of particular types of branching in diagrams of confidence intervals show similar pattern differing in their course maximally by a value of $1 \mathrm{~mm}$ increment providing no reliable background for visible differentiation of growth in particular types of branching. Annual ring curves in Fig. 7 make it possible to reveal the course of growth in particular types of branching. Up to the year 1988, i.e. 30-year-old stand, differences in increment do not exceed $1 \mathrm{~mm}$. In 1998, however, the largest difference in radial increment amounted to $1.5 \mathrm{~mm}$, i.e. $3 \mathrm{~mm}$ in diameter. Such a difference can be already evident under conditions of increment accumulation.

In the diagram, there are changes in the order of increment values particularly in the comb-shaped/fascicle type of branching. At the beginning of our study, i.e. in 1972, the type of branching shows the smallest radial increment, however, in 1998, the increment is greatest. Virtually visible radial increment is best demonstrated by cumulative curves (Fig. 8). 

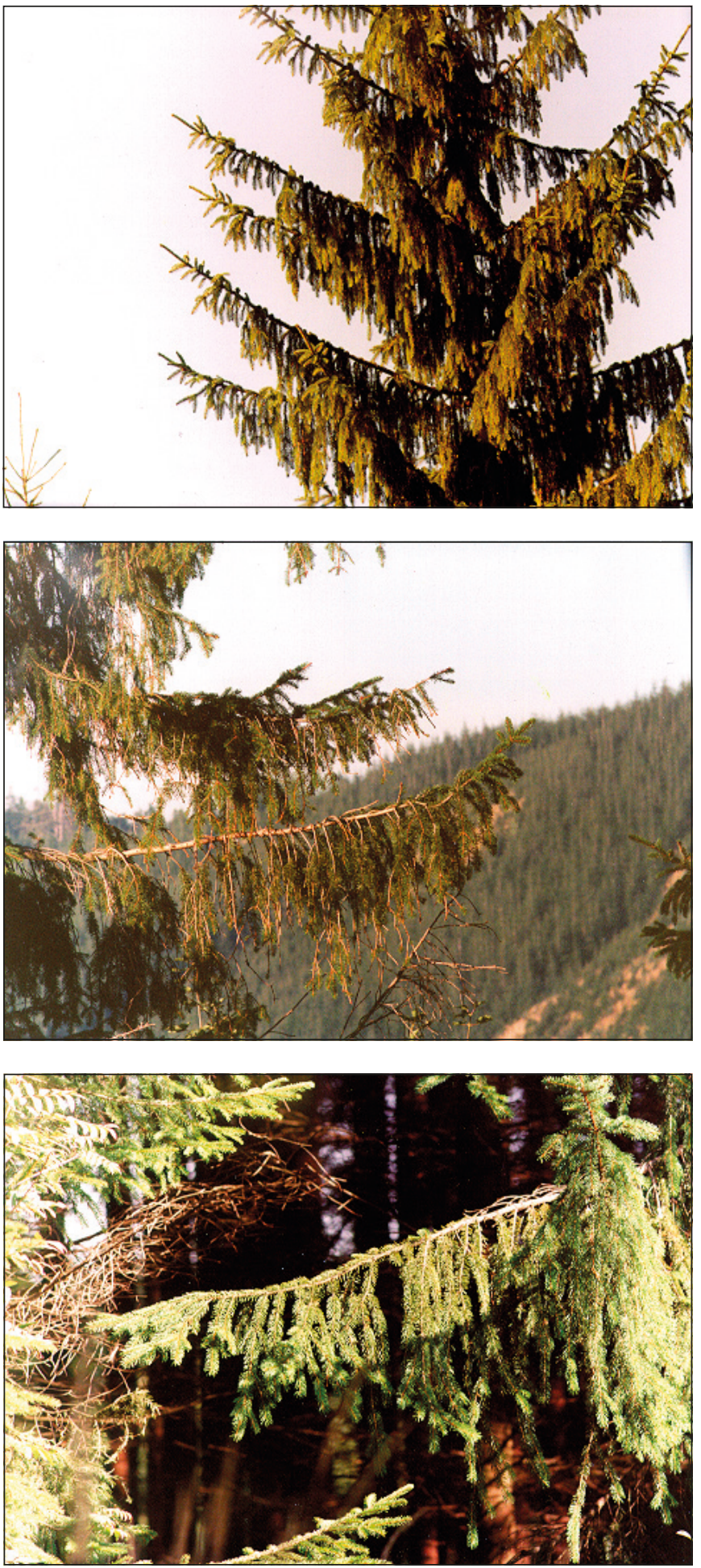

Fig. 2: Details of comb-shaped branching (1) for three different individuals. Photo O. Hauck, 1999. 

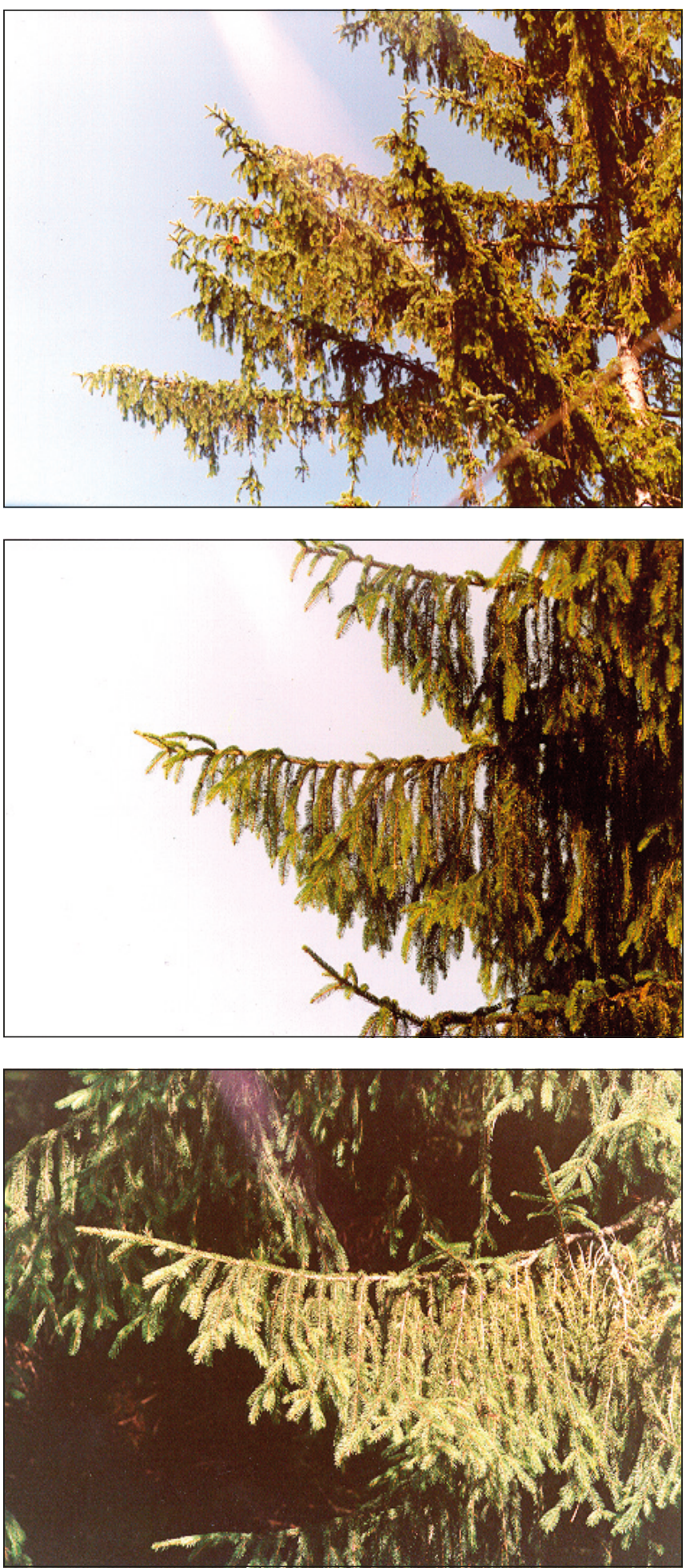

Fig. 3: Details offascicle/comb-shaped, comb-shaped/fasciclebranching (1/2) forthree different individuals. Photo O. Hauck, 1999. 

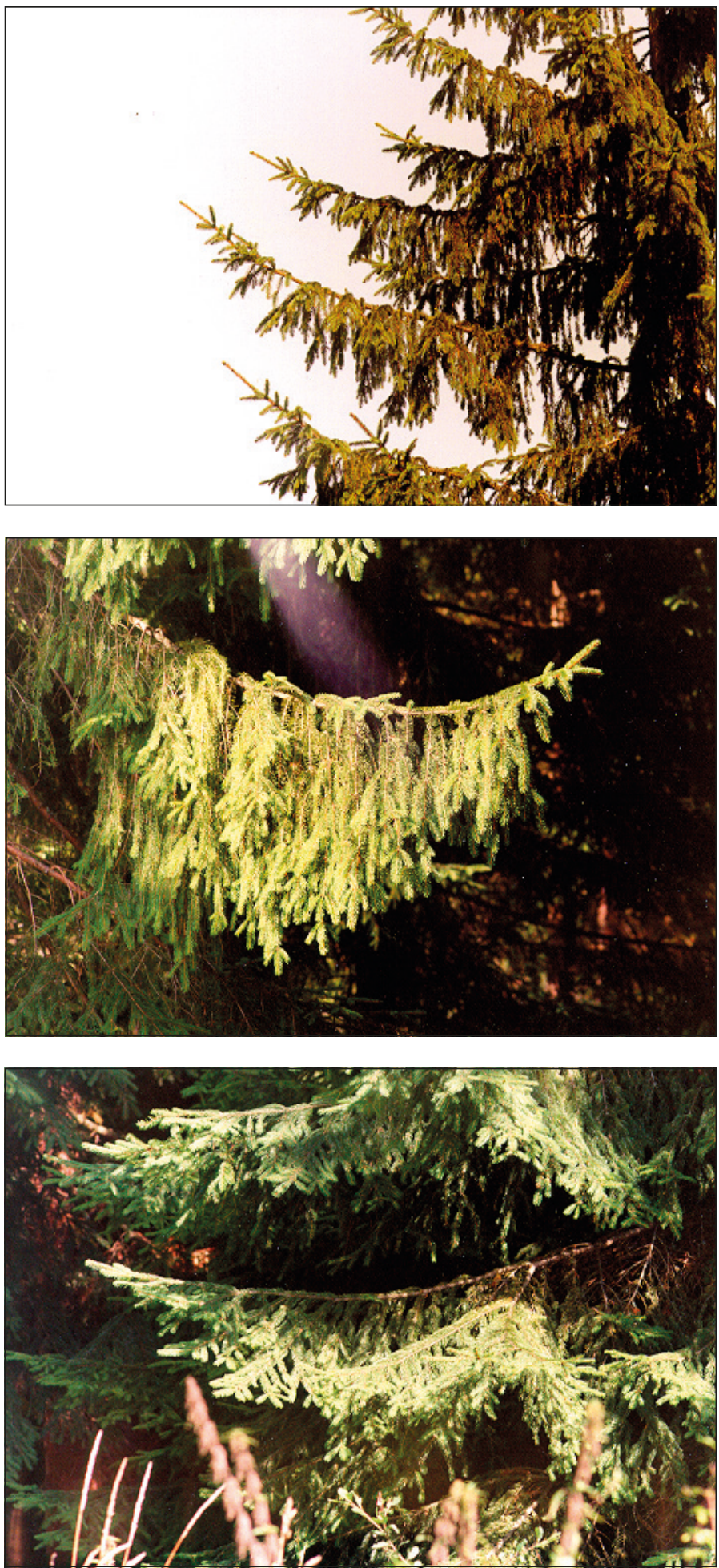

Fig. 4: Details of fascicle branching (2) for three different individuals. Photo O. Hauck, 1999. 

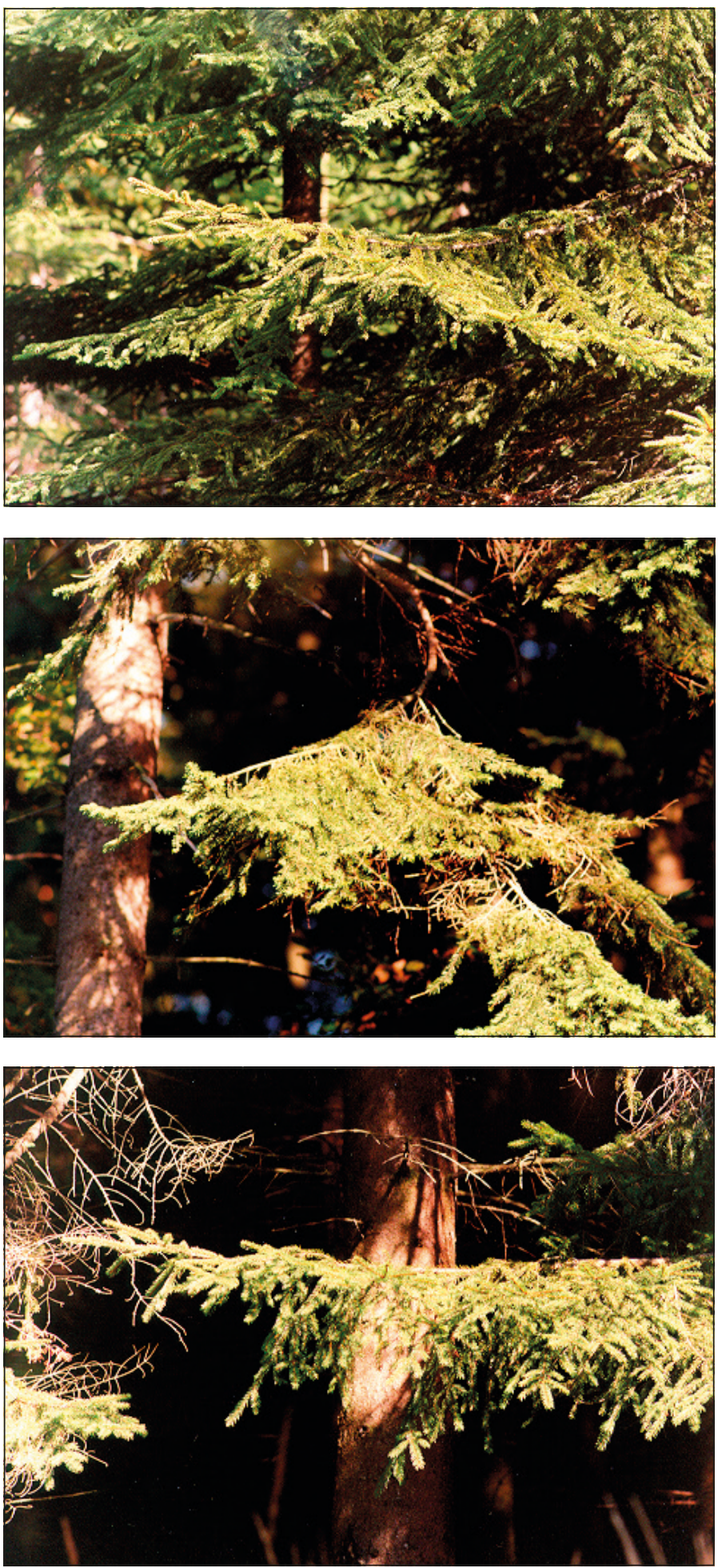

Fig. 5: Details of plate-shaped/fascicle, fascicle/plate-shaped branching (2/3) for three different individuals. Photo O. Hauck, 1999. 

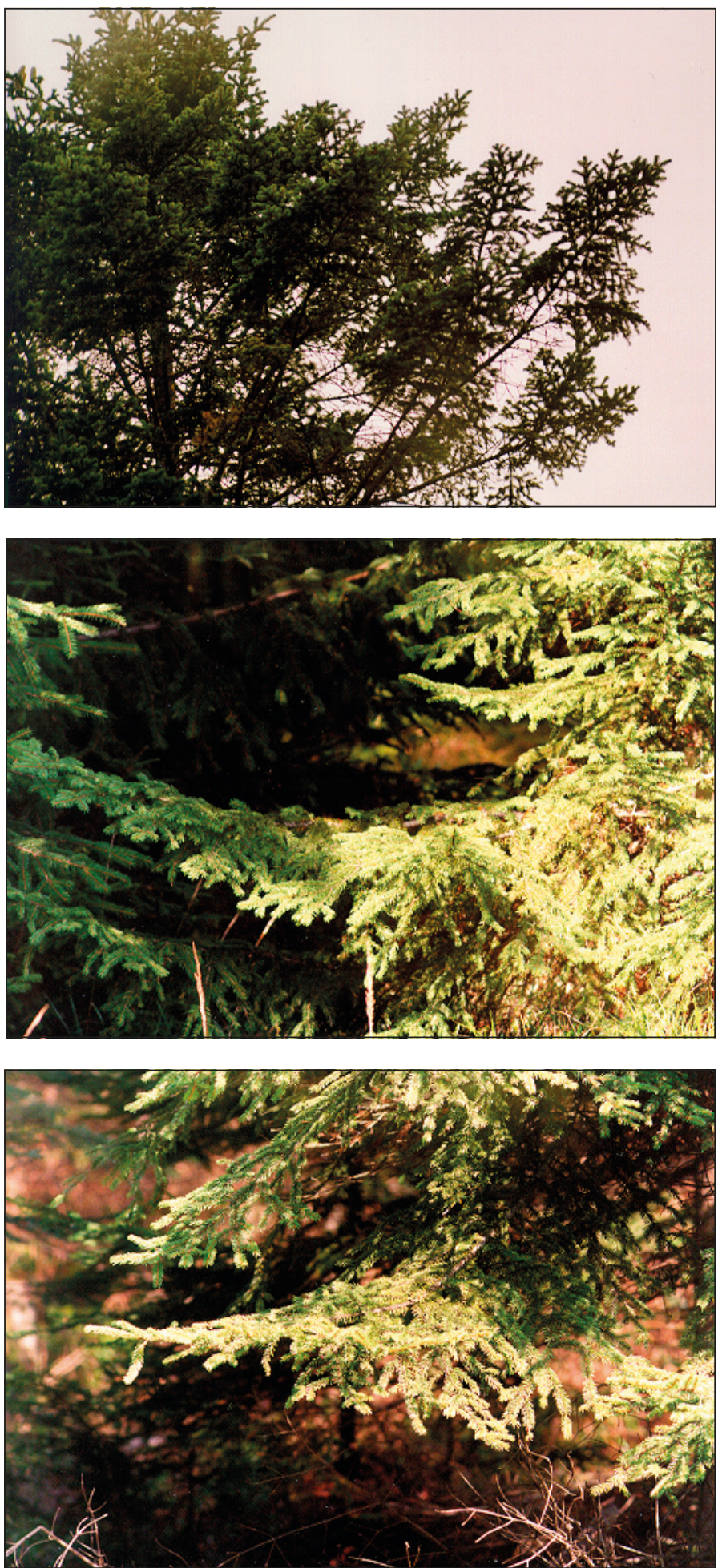

Fig. 6: Details of plate-shaped branching (3) for three different individuals. Photo O. Hauck, 1999. 


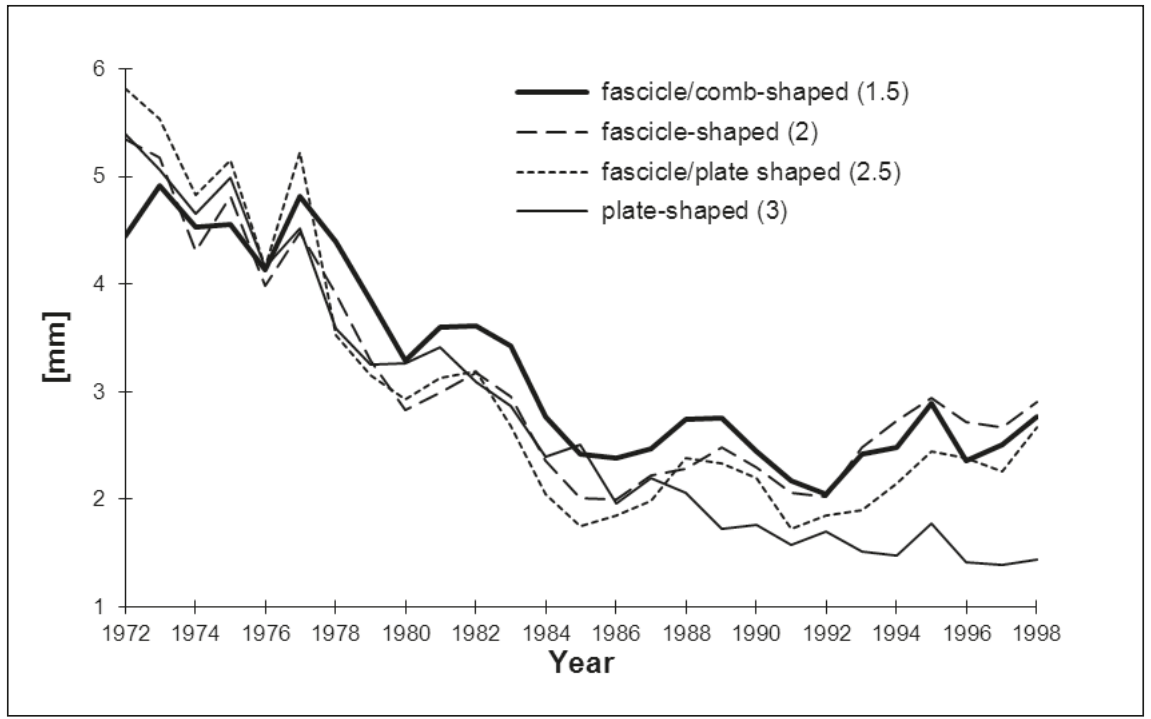

Fig. 7: Annual ring curves of spruce trees aged 18-44 years according to particular types of branching, SP Bíly Kř⿰氵亡 .

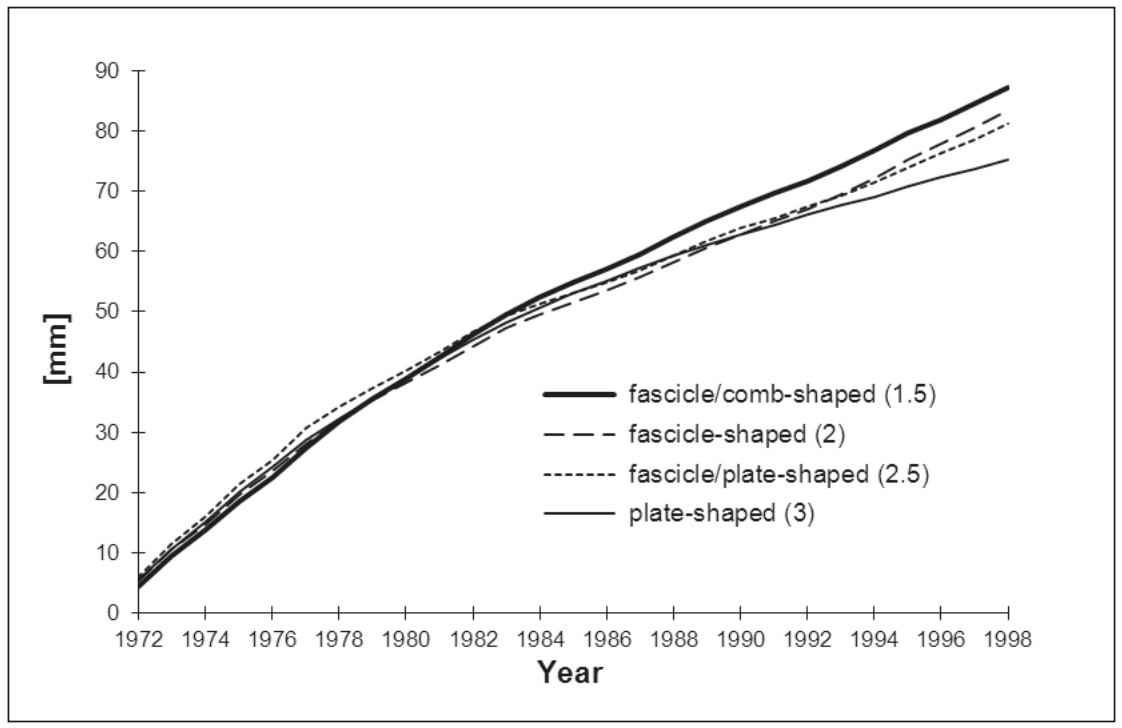

Fig. 8: Cumulative curves of annual diameter increments of spruce trees aged 18-44 years according to particulartypes of branching, SP Bílý Kř̌z:

Originally very similar curves running closely side by side begin to differentiate in 1985 (stand age 27 years) and in 1998, the size of radial increments exhibit an order which is known from older stands, i.e. from the smallest for the plate-shaped type to the largest for the combshaped/fascicle type. The course of annual ring curves evidently corresponds to the course of branching type differentiation which begins to differ after 25 years of the stand age as already mentioned. Thus, virtually visible changes in radial increment occur simultaneously with branching differentiation so that the character of growth in a young tree cannot serve for the early differentiation of particular types of branching as supposed on the basis of literature data (Hauck, Palát 2000).

Confidence intervals of the radial increment of spruce for the Bílý Kř́ž locality is presented in Figs. 9-11. 


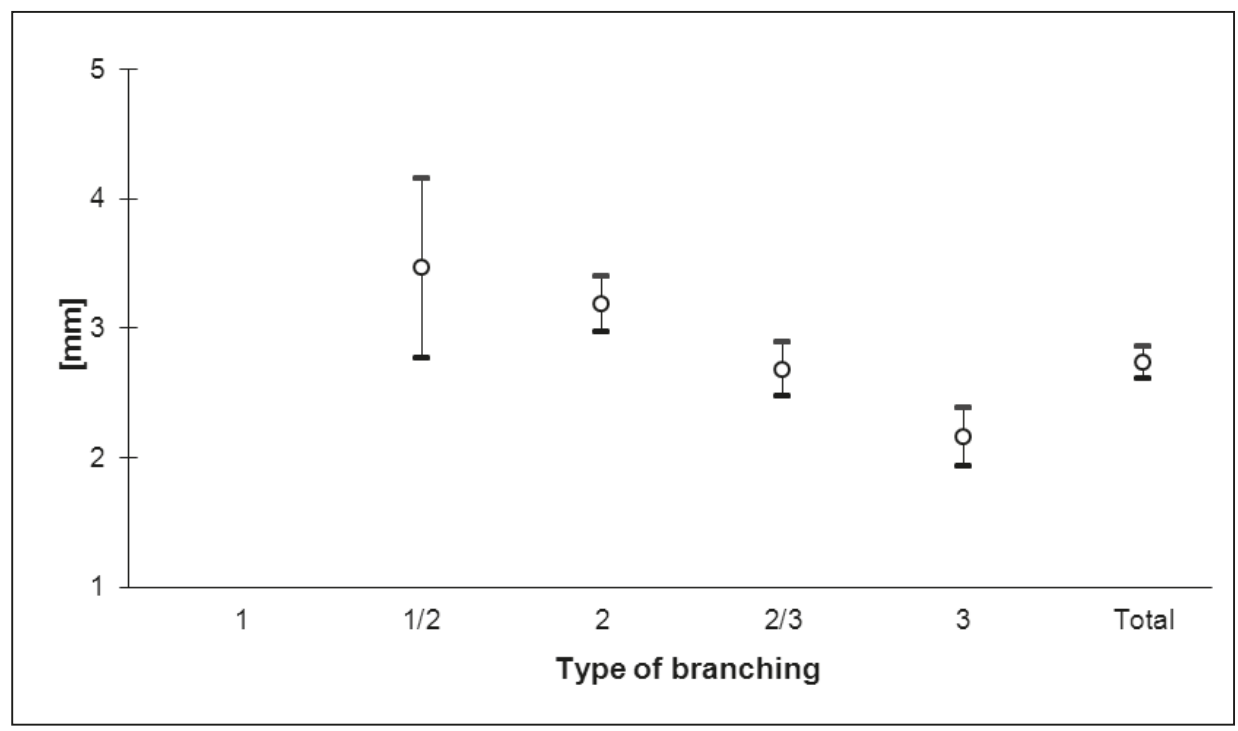

Fig. 9: Confidence intervals $(P=0.05$ ) of the annual radial increment of spruce in 1987-91 for four types of branching and in total, the Bílý Kríz locality.

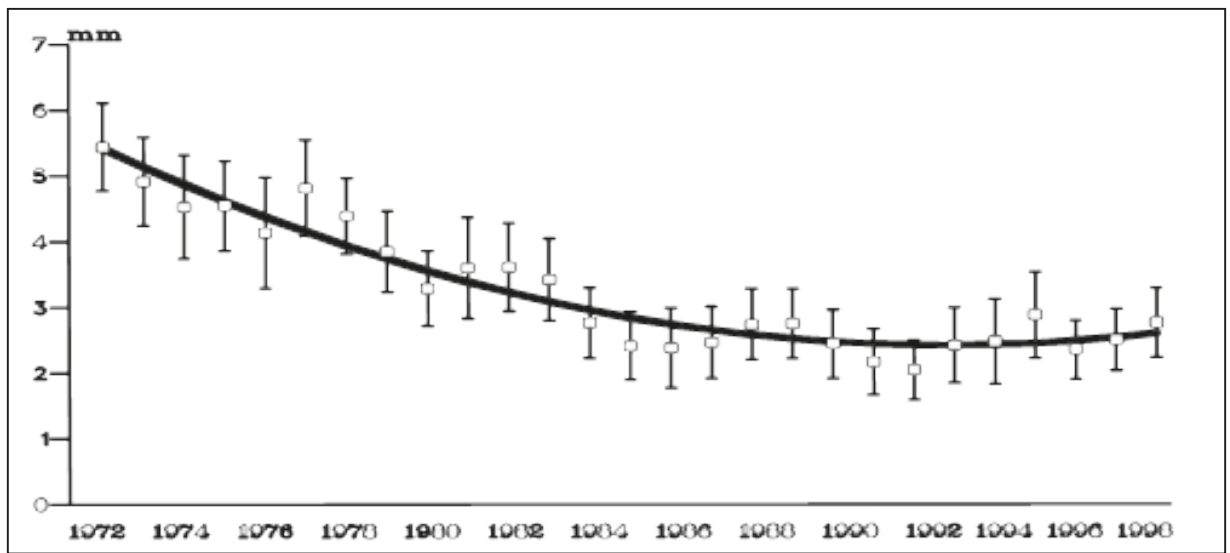

Fig. 10: Confidence intervals ( $P=0.05$ ) of annual radial increment for type of branching 1.5, Bíly Krí̌, Norway spruces 44 old.

On the basis of confidence intervals for $\mathrm{P}_{0,05}$ of the annual radial increment in 1987-1991 for markedly represented types of branching for SP decrease from the greatest value for the combshaped/fascicle type to the plate-shaped type.

Data from the destructive analyses (Vyskot 1981, 1985) were fitted by means of regression and correlation analysis in order to study the relationships between selected characteristics of the sample trees (Grossmann 1991; Palát 1985,
1991, 1997; Palát et all. 1992, 1994, 1999) and the resulting regression functions for the construction of models.

A selection was carried out of 14 regression equations from a total of 59 equations characterizing both biomass fractions and a number of other characteristics. Selected dependences are depicted in Figs. 12-19. Biomass of stem in relation to d.b.h., incl. data of Bílý Kř́źz locality is presented in Fig. 20. 


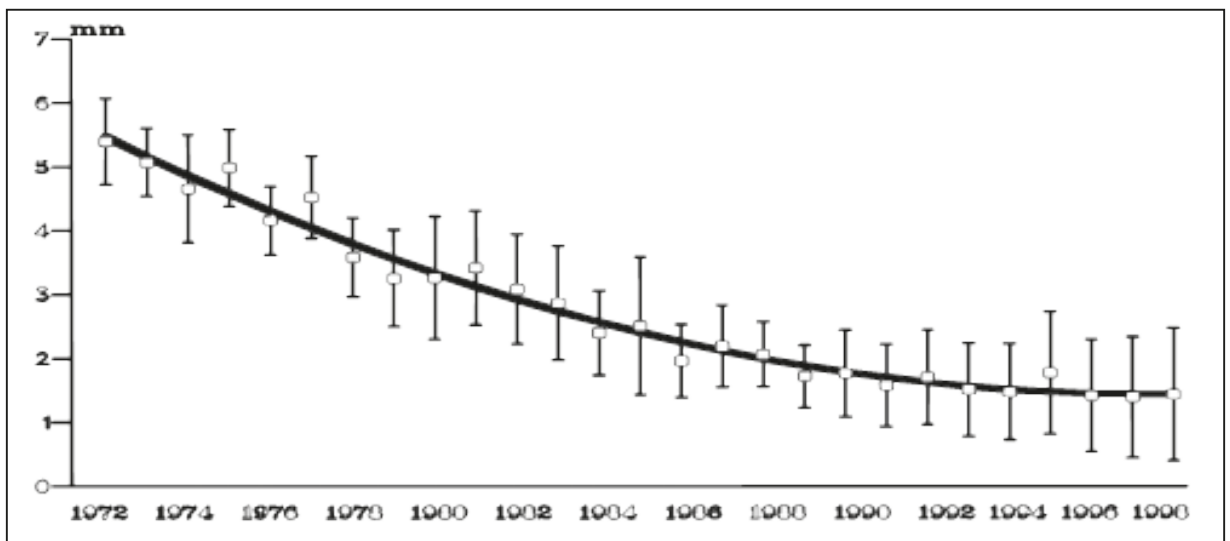

Fig. 11: Confidence intervals ( $P=0.05$ ) of annual radial increment for type of branching 3, SP Bílý Kř́̌̌, Norway spruces 44 old.

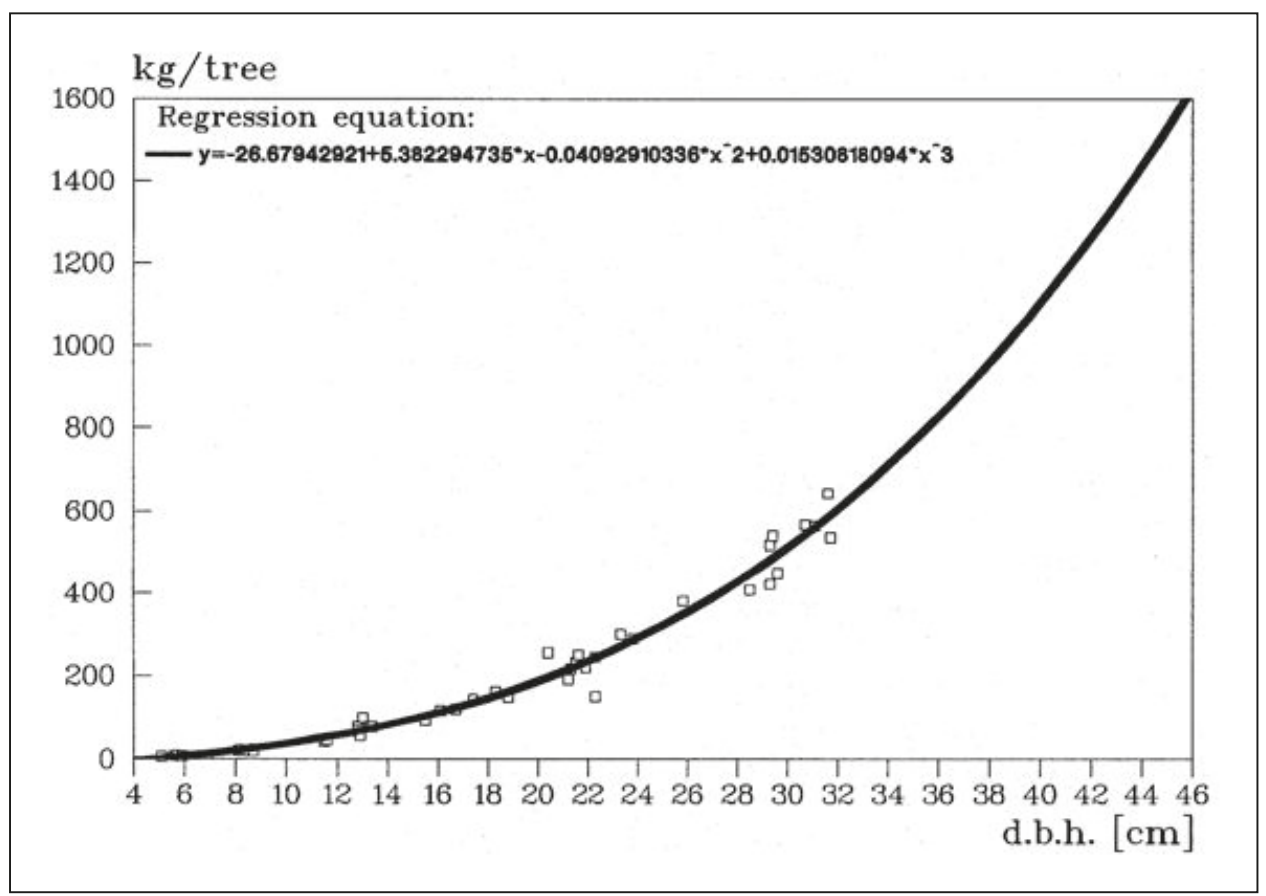

Fig. 12: Above-ground biomass in relation to the d.b.h. 


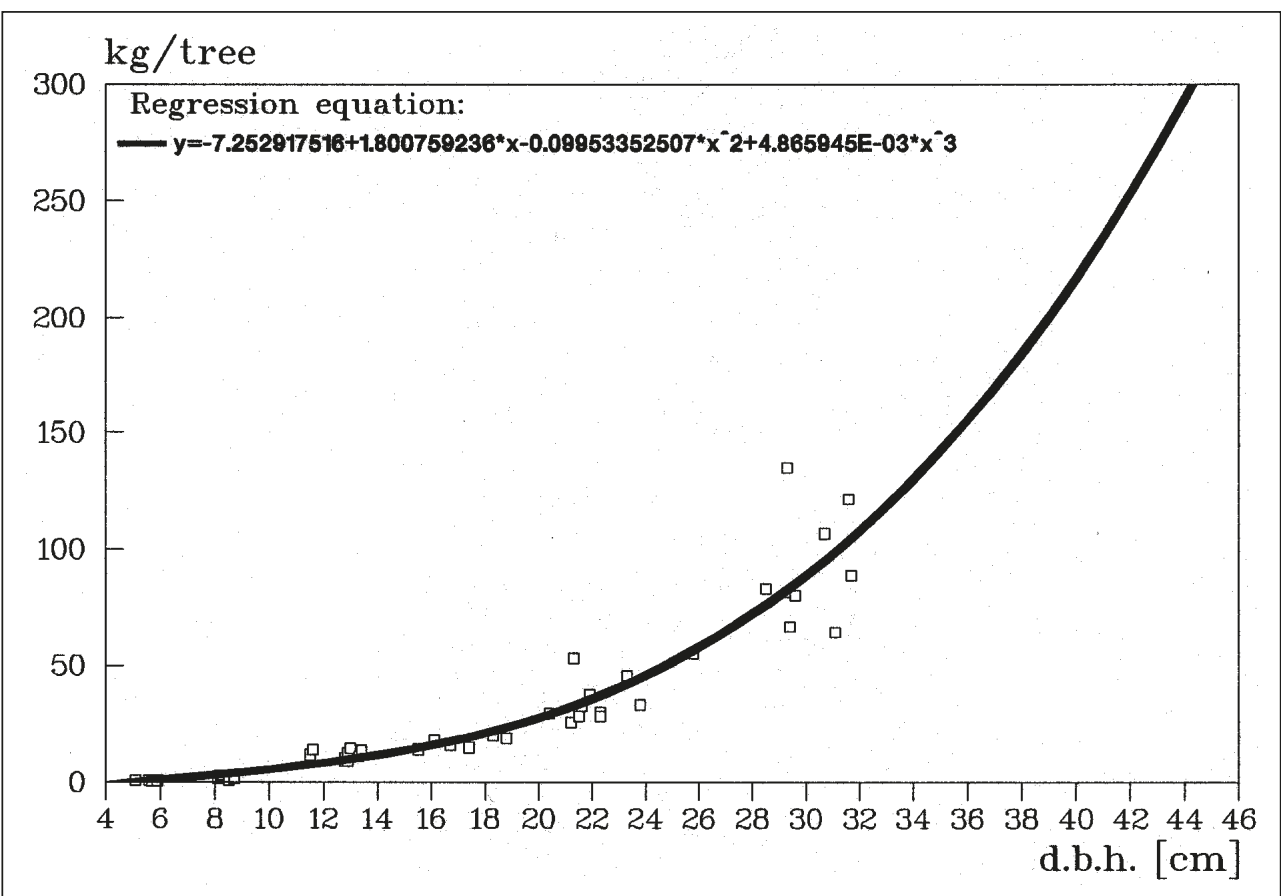

Fig. 13: Underground biomass in relation to the d.b.h.

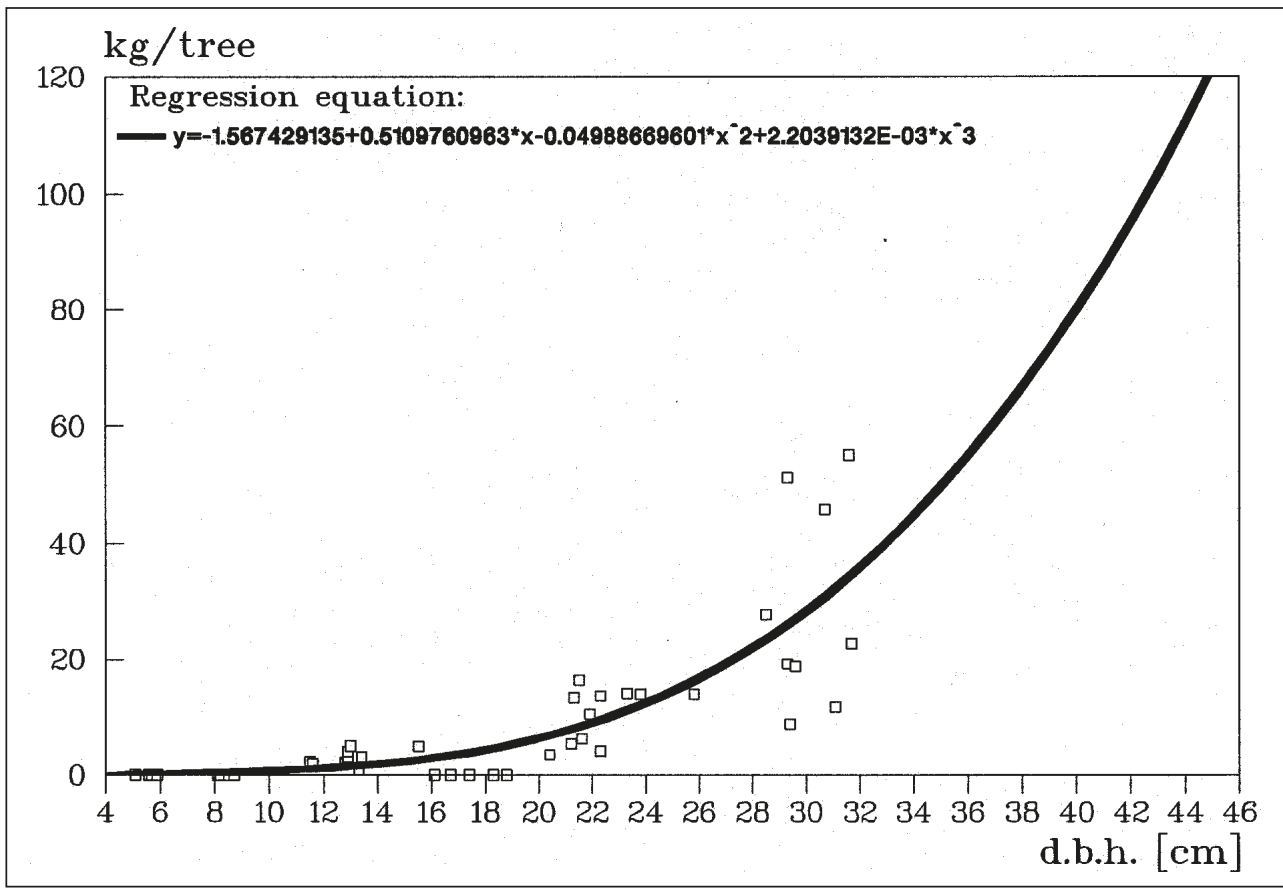

Fig. 14: Biomass of roots above $5 \mathrm{~cm}$ in diameter in relation to the d.b.h. 


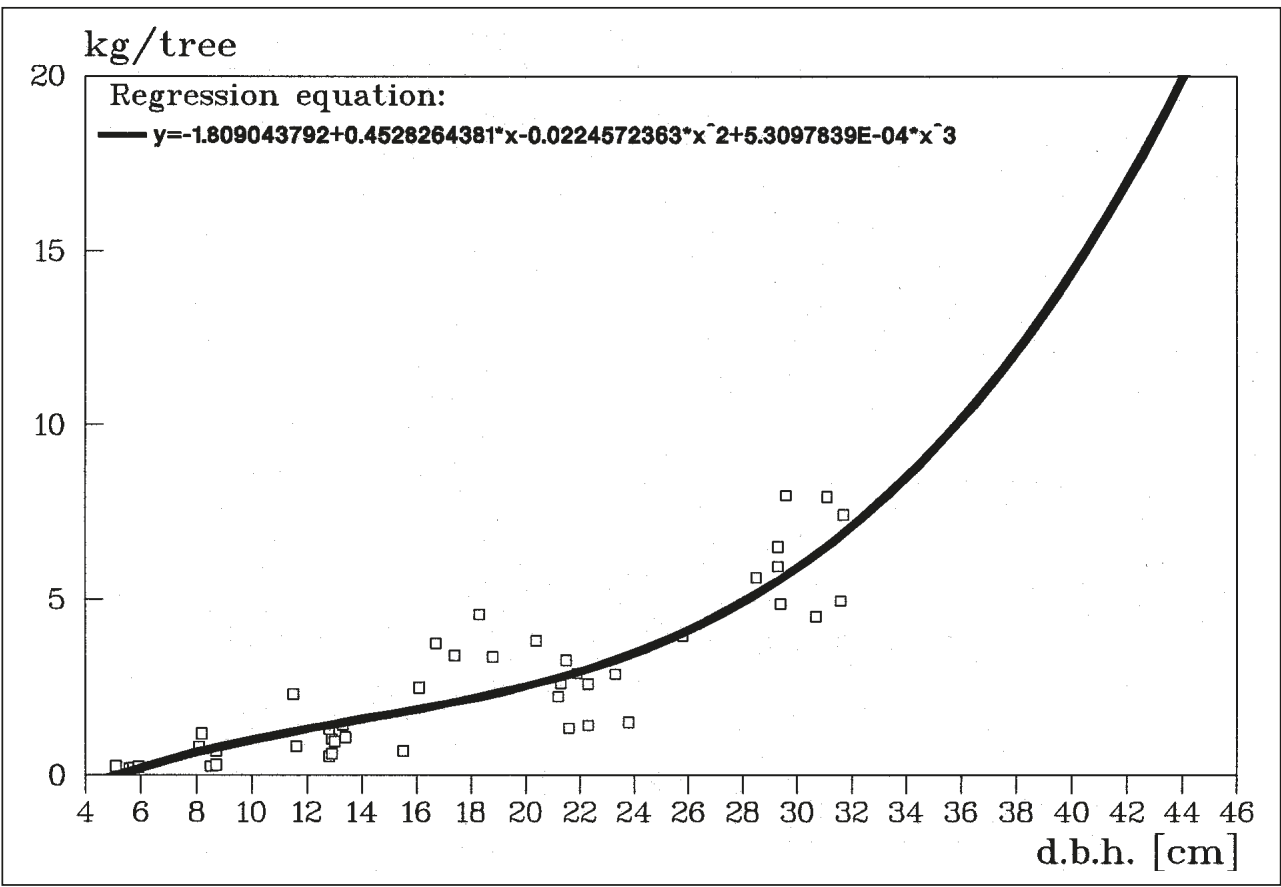

Fig. 15: Biomass of roots from 2.1 to $5 \mathrm{~cm}$ in diameter in relation to the d.b.h.

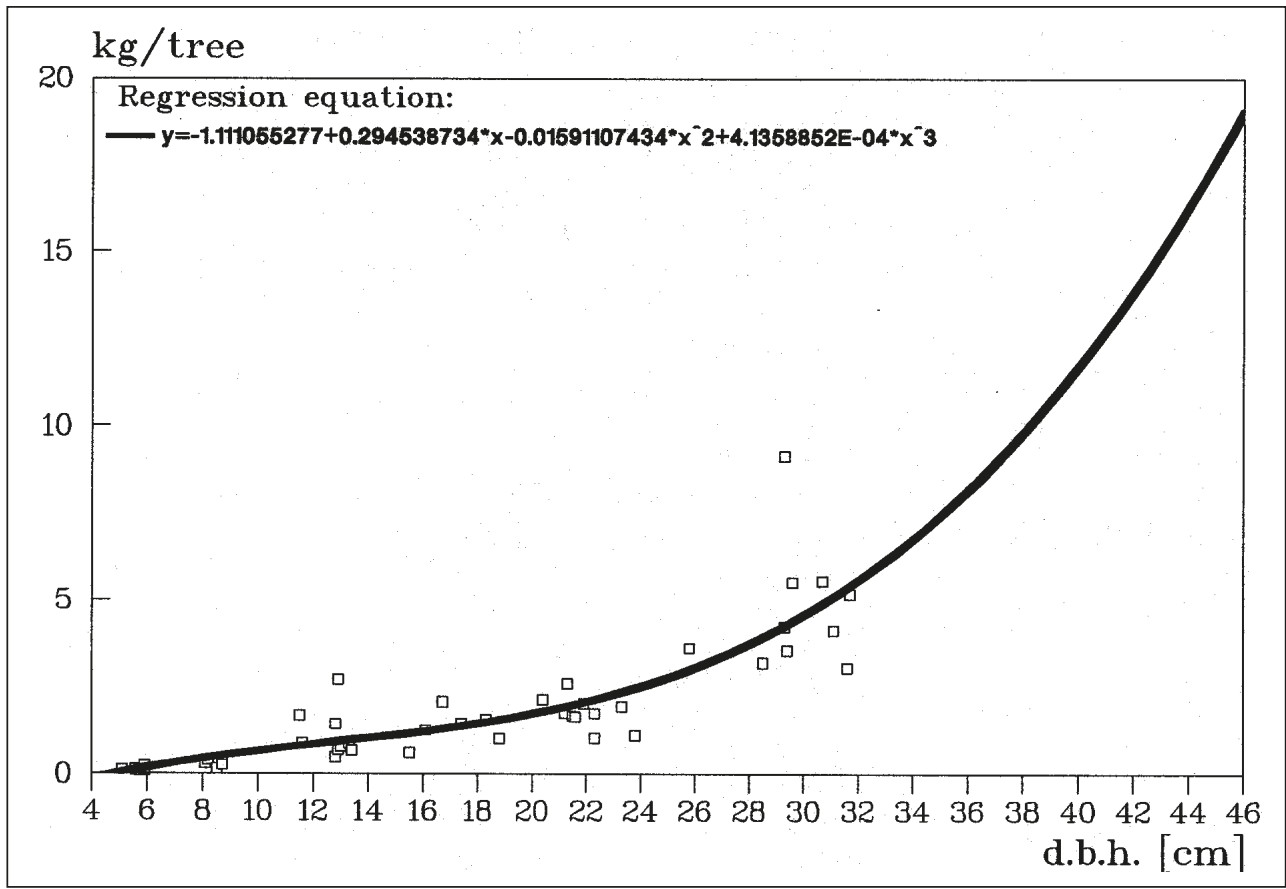

Fig. 16: Biomass of roots from 0.1 to $2 \mathrm{~cm}$ in diameter in relation to the d.b.h. 


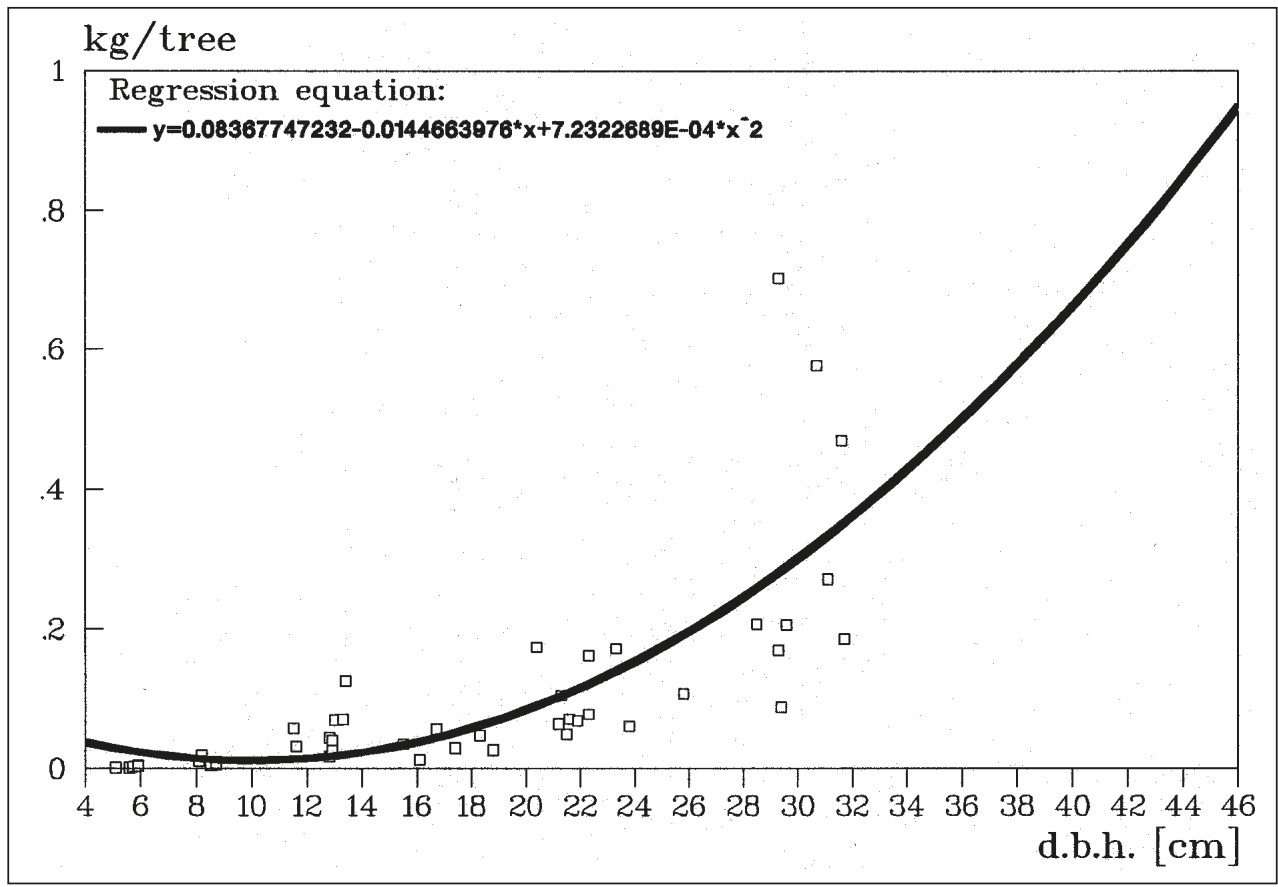

Fig. 17: Biomass of roots under $0.1 \mathrm{~cm}$ in diameter in relation to the d.b.h.

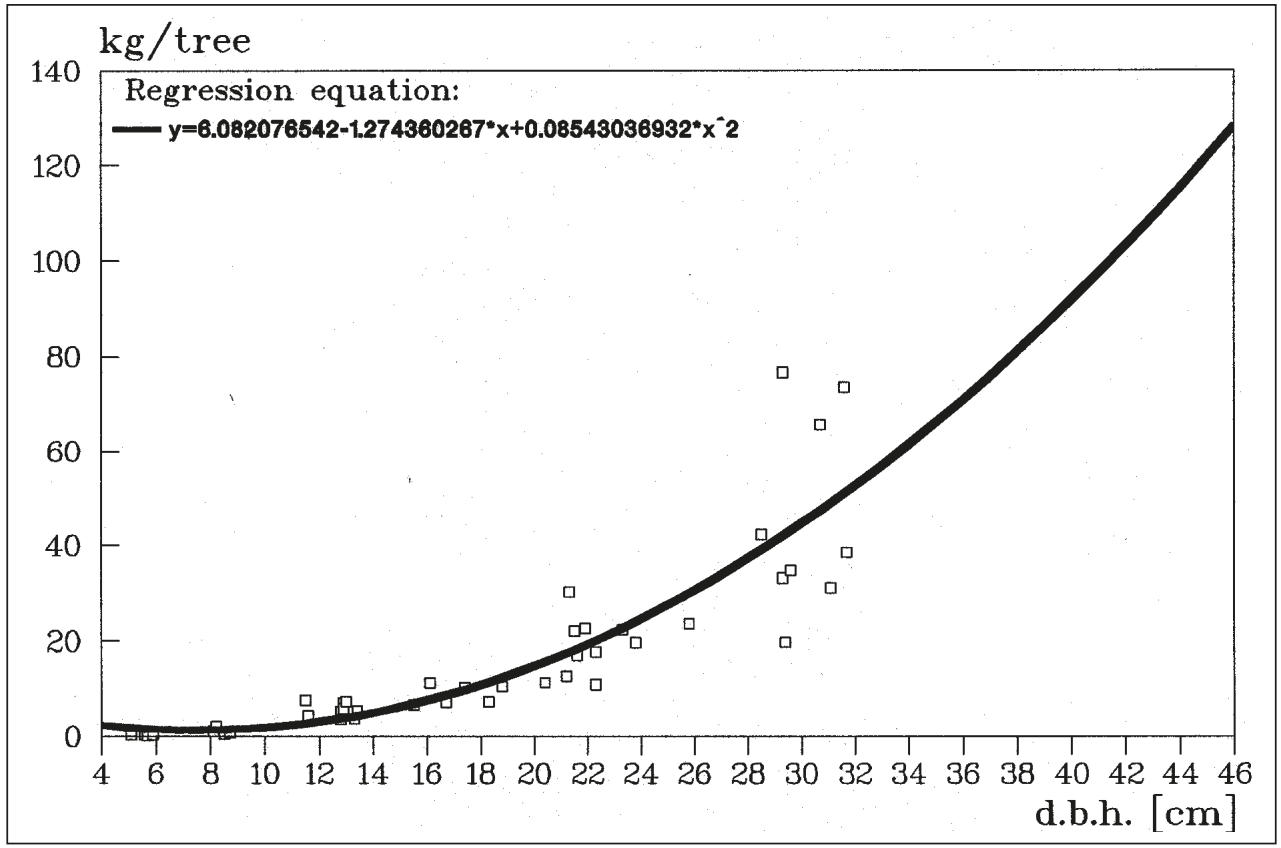

Fig. 18: Biomass of roots and root swellings without stump in relation to the d.b.h. 


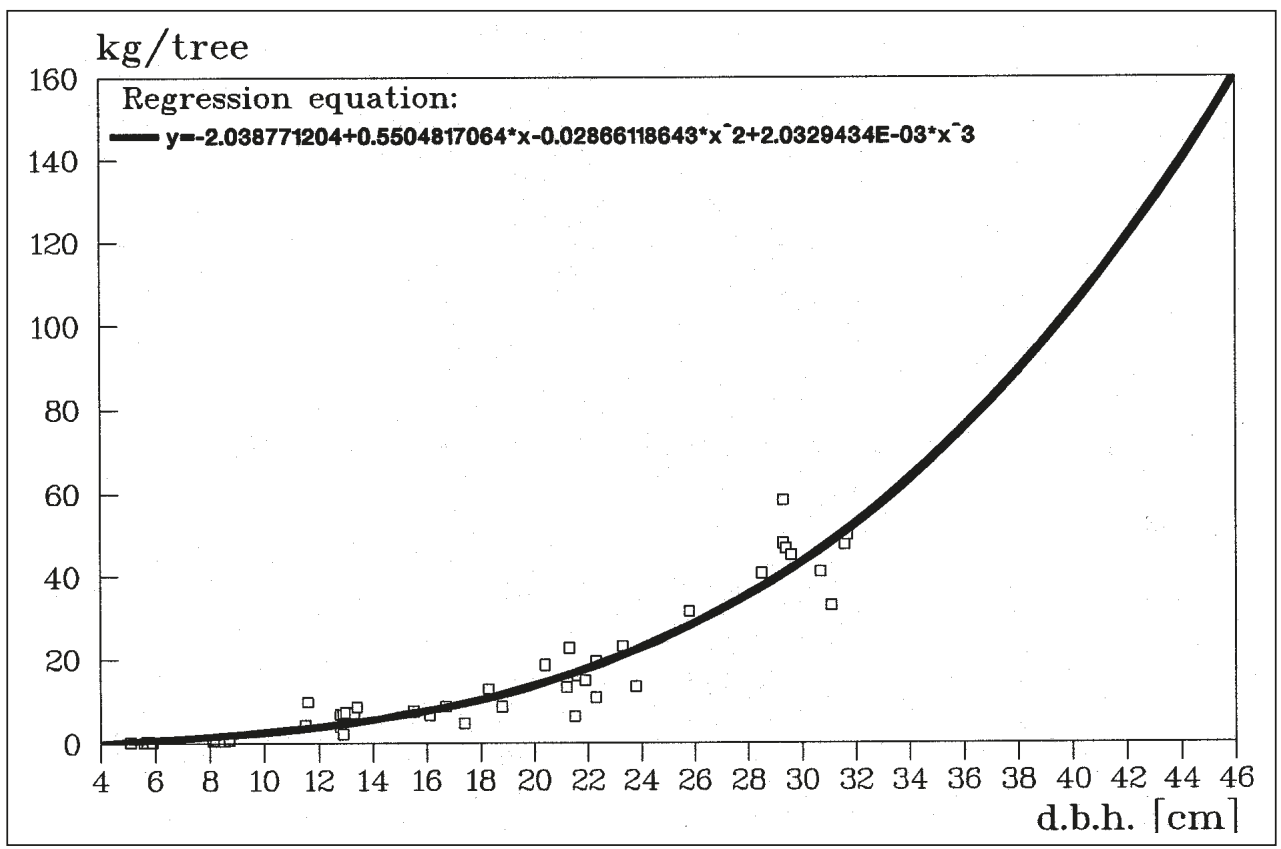

Fig. 19: Biomass of stumps in relation to the d.b.h.

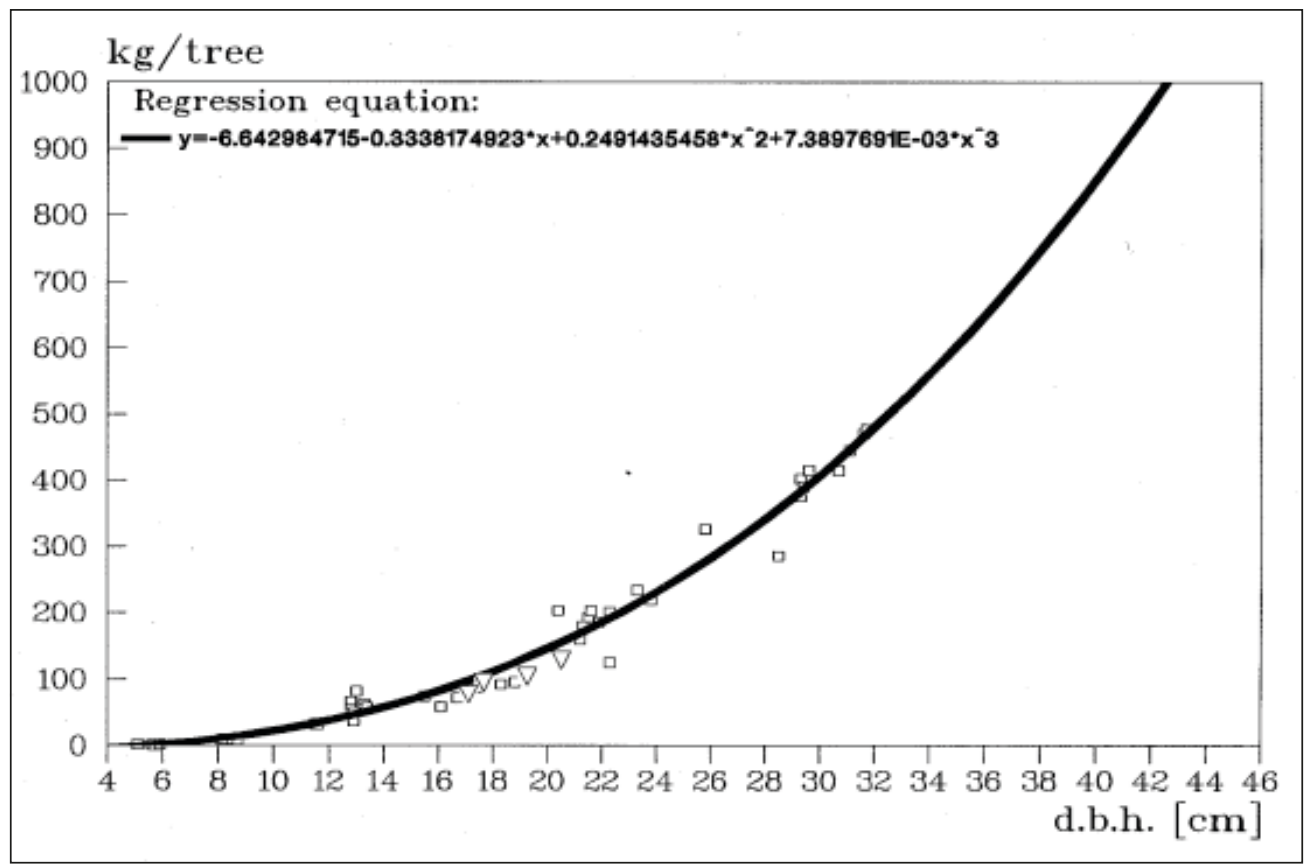

Fig. 20: Biomass of stem in relation to d.b.h., incl. Data od Bílý Kř́úlocality ( $\nabla)$. 
For a man-made Norway spruce ecosystem regression functions determined by fitting the data from 45 sample spruce trees were derived. Various fractions of the biomass of trees with diameter over $4 \mathrm{~cm}$ were calculated in 1981, 1981 and 1991. Selected two PSP are presented in Tab. 1-2.

Tab. 1: Biomass fractions ( $k g$ DMha $\mathrm{H}^{-1}$ ) computed on the basis of regression equations calculated on data from sampletrees PSP E 4005.

\begin{tabular}{lrrr}
\hline \multicolumn{1}{c}{ Year } & 1981 & 1986 & \multicolumn{1}{c}{1991} \\
\hline Number of trees & 533 & 533 & 515 \\
Needles & 26826 & 30230 & 31873 \\
Shoots & 11386 & 12664 & 13224 \\
Branches & 21800 & 24341 & 25488 \\
Stem (large timber) & 267009 & 304666 & 324442 \\
Stem (small timber) & 4005 & 4144 & 4107 \\
Total above-ground & 341348 & 391815 & 419506 \\
Total underground & 63028 & 74073 & 80735 \\
Total & 404377 & 465888 & 500241 \\
Roots above 5 cm & 21711 & 26175 & 29037 \\
Roots from 2.1 to 5 cm & 4247 & 4988 & 5455 \\
Roots from 0.1 to 2 cm & 3363 & 3984 & 4380 \\
Roots under 0.1 cm & 200 & 231 & 246 \\
Roots and root swellings without stumps & 28917 & 32852 & 34807 \\
Stumps & 30593 & 35794 & 38872 \\
\hline
\end{tabular}

Tab. 2: Biomass fractions ( $\mathrm{kg} \mathrm{DMha} \mathrm{a}^{-1}$ ) computed on the basis of regression equations calculated on data from sample trees PSP E 4024.

\begin{tabular}{lrrr}
\hline \multicolumn{1}{c}{ Year } & \multicolumn{1}{c}{$\mathbf{1 9 8 1}$} & $\mathbf{1 9 8 6}$ & \multicolumn{1}{c}{$\mathbf{1 9 9 1}$} \\
\hline Number of trees & 555 & 555 & 545 \\
Needles & 21001 & 23999 & 25361 \\
Shoots & 9071 & 10217 & 10702 \\
Branches & 17356 & 19609 & 20585 \\
Stem (large timber) & 206881 & 239500 & 255317 \\
Stem (small timber) & 3736 & 3876 & 3882 \\
Total above-ground & 265155 & 308401 & 330176 \\
Total underground & 48058 & 57297 & 62334 \\
Total & 313213 & 365698 & 392511 \\
Roots above 5 cm & 16085 & 19755 & 21863 \\
Roots from 2.1 to 5 cm & 3350 & 3963 & 4313 \\
Roots from 0.1 to 2 cm & 2612 & 3124 & 3418 \\
Roots under 0.1 cm & 152 & 178 & 190 \\
Roots and root swellings without stumps & 22259 & 25697 & 27284 \\
Stumps & 23350 & 27722 & 30065 \\
\hline
\end{tabular}




\section{Conclusions}

The fascicle (45\%) and plate-shaped/fascicle (31\%) types of branching appear to be the most distributed types of branching in the region of the Beskids represented by our sample plots (SP). Transitional comb-shaped/fascicle and fascicle/plate-shaped types are represented by $11-12 \%$ of trees. The comb-shaped type of branching occurred only in 10 trees, i.e. $<1 \%$. With respect to the fact that according to our studies the plate-shaped and fascicle/plateshaped types show significantly smaller increments (both in diameter and height) and, at the same time, are heavily affected by breaks, it is possible to remove them particularly in the course of thinning operations with the exception of ridge locations where just the types are suitable being more resistant to the effects of wind. Types showing larger increment (combshaped and fascicle/comb-shaped types) should be supported if they are present in stands and unless they suffer from considerable breaks. In the region of the Hrubý Jeseník Mts. represented by three PSP, the plate-shaped $(50 \%)$ and fascicle types of branching are most distributed. The transitional fascicle /plate-shaped type is represented by $15.8 \%$ and the comb-shaped/ fascicle type by only $1.5 \%$ of trees. The combshaped type of branching was quite absent.

On the basis of field survey conducted in the Beskids and in the Krrtiny Training Forest Enterprise it is possible to say that particular phenotypes can be reliably distinguished from 25-30 years of age, i.e. the pole-stage stand (d.b.h. $13-19 \mathrm{~cm}$ ). It is not recommended to carry out the classification in young age due to possible great errors. Annual ring analyses of spruce trees in Bílý Kříž locality show that diameter increment differentiation caused by the type of branching occurs simultaneously with branching type differentiation between twenty and thirty years of age so that diameter differences appearing earlier cannot be used as an auxiliary characteristic for determining the type of branching.

For a man-made Norway spruce ecosystem regression functions determined by fitting the data from 45 sample spruce trees were derived (at Drahanská Upland) and used also for sample plots in Beskids. Various fractions of the biomass of trees with diameter over $4 \mathrm{~cm}$ were calculated in 1981, 1981 and 1991. Selected two PSP are presented in Tab. 1-2.

\section{References}

Grossmann, W.D. 1991: Einsatz von dynamischen Modellen in der Waldschadensproblematik. Konzept, Probleme und Ergebnisse im Lehrforst Rosalia. Zentralblattfürdas Forstwesen, Wien.

Hauck, O., Palát, M. 2000: Norway spruce increment and stress as related to the type of branching. Ekológia (Bratislava), 19, Supplement 1/2000: 177-189.

Palát, M. 1980: Ecosystem modelling and its application to selected floodplain forest ecosystem (in Czech). Research report, VŠZ, 85 pp.

PaLÁt, M. 1985: Mathematical models of processes and stability of Norway spruce and floodplain forest ecosystems (in Czech). Research report, VŠZ, 215 pp.

Palát, M. 1991: Model of the organic matter flow in a representative of the foodplain forest. In: PENKA, M., Vysкот, M., Кцimo, E., VAšíčeK, F. (Eds.), Floodplain forest Ecosystem. 2. After Water Management Measures, Academia Praha/ Elsevir Amsterdam, pp. 265-277.

PaLÁt, M. 1997: Biomass flow in a floodplain forest ecosystem and in man-made Norway spruce forest. Forestry, 43 (10): 441-452.

Palát, M., Janíček, R., Matovič, A. 1992: Biomass and tree production of a spruce monoculture. In: Klimo, E., MaršÁleK, J. (Eds.), Manmade Spruce Ecosystem. Report from project Rájec. Univ. of Agriculture Brno, pp. 37-53.

Palát, M., PokornÝ, P. 1999: Forest Soil Monitoring in Permanent Sample Plots in the Czech Republic. SOIL MONITORING - Proceedings from the IV. International conference, Brno, hotel Voroněž 31 May - 1 June 1999. Central institute for supervising and testing in agriculture in Brno, 72-74. ISBN 80-86051-43-9

Palát, M., Vašíček, F., Henžlík, V., Kasperidus, H.D. 1994: Condition of Damage to Norway Spruce Stands in the Czech Republic. Lesnictvi - Forestry, 40 (6): 217-237.

SAMEK, V. 1964: Research methodology of morphological variability of tree species from point of view phytogeography. Research report, Zbraslav Strnady, $28 \mathrm{pp}$.

Vүзкот, M. 1981: Biomass od the tree layer of a spruce forest in the Bohemian Uplands. Praha, Academia: 396 pp.

Vyskot, M. 1985: The tree layer. In: Penka, M., Vysкot, M., Kцimo, E., VAš́̌́̌́, F. (Eds.), Floodplain forest Ecosystem 1., Academia Praha/Elsevir Amsterdam, 265-277. 